\title{
Water-Quality and Fish-Community Data for the Niobrara National Scenic River, Nebraska, 2003-05
}

\section{Introduction}

In 1991, a 76-mile reach of the Niobrara River in northcentral Nebraska was designated as a National Scenic River (NSR). This reach of the river hosts a unique ecosystem that provides habitat for a diverse fish and wildlife population that include several threatened and endangered species. The Niobrara NSR also is a popular destination for campers, canoeists, kayakers, and tubers.

Changes in surface-water quality, related to recreation, industrial and municipal discharge, and agricultural activities in the region have the potential to affect fish and wildlife populations within the Niobrara NSR. Additionally, water users may be at risk if elevated concentrations of chemical or biological contaminants are present in the waterway. The U.S. Geological Survey (USGS) and the National Park Service (NPS) began a 3-year cooperative study of water-quality characteristics in Niobrara NSR in 2003. During the study, water samples were collected for analysis of a suite of physical, chemical, and biological indicators of water quality in the Niobrara River. The resulting data have been published previously (Hitch and others, 2004; Hitch and others, 2005) and included: major ions, nutrients, trace elements, pesticides, organic (wastewater) compounds, bacteria, and suspended sediment. In addition to waterquality sampling, fish communities were sampled to identify the presence and diversity of species at selected sites (data available online in Annual Water Data Reports). These water-quality and fish-community data are summarized in this report. The data were collected to provide baseline information that will help NPS managers determine if changes in recreational activities, land-use practices, and other factors are affecting the Niobrara River.

\section{Background}

The Niobrara River extends 536 miles from eastern Wyoming to its mouth near Niobrara, Nebraska. Streamflow within the basin is derived primarily from snowmelt and seepage from the underlying High Plains aquifer. Flows are usually highest in the spring and early summer and lowest in late summer and early fall. Land use in the Niobrara River Basin primarily consists of rangeland, alfalfa, and row crops. Minnechaduza Creek, a small tributary to the Niobrara River, located on the northern edge of Valentine, Nebraska, the largest community in the sparsely populated region, receives runoff and treated wastewater discharge from the city.

The Niobrara NSR designation begins near Valentine and extends 76 miles downstream to north of Newport, Nebraska, and encompasses 23,000 acres of open water, forests, hills, prairies, and canyons. The area received approximately 53,400 visitors in 2004 (National Park Service, 2005). Although recreation activities take place year-round, the greatest public use occurs from mid-May to mid-October.

The study area includes the 35-mile reach of the Niobrara NSR from the Borman Bridge to the Carns Bridge (fig. 1). Four sites were selected to monitor water-quality conditions from

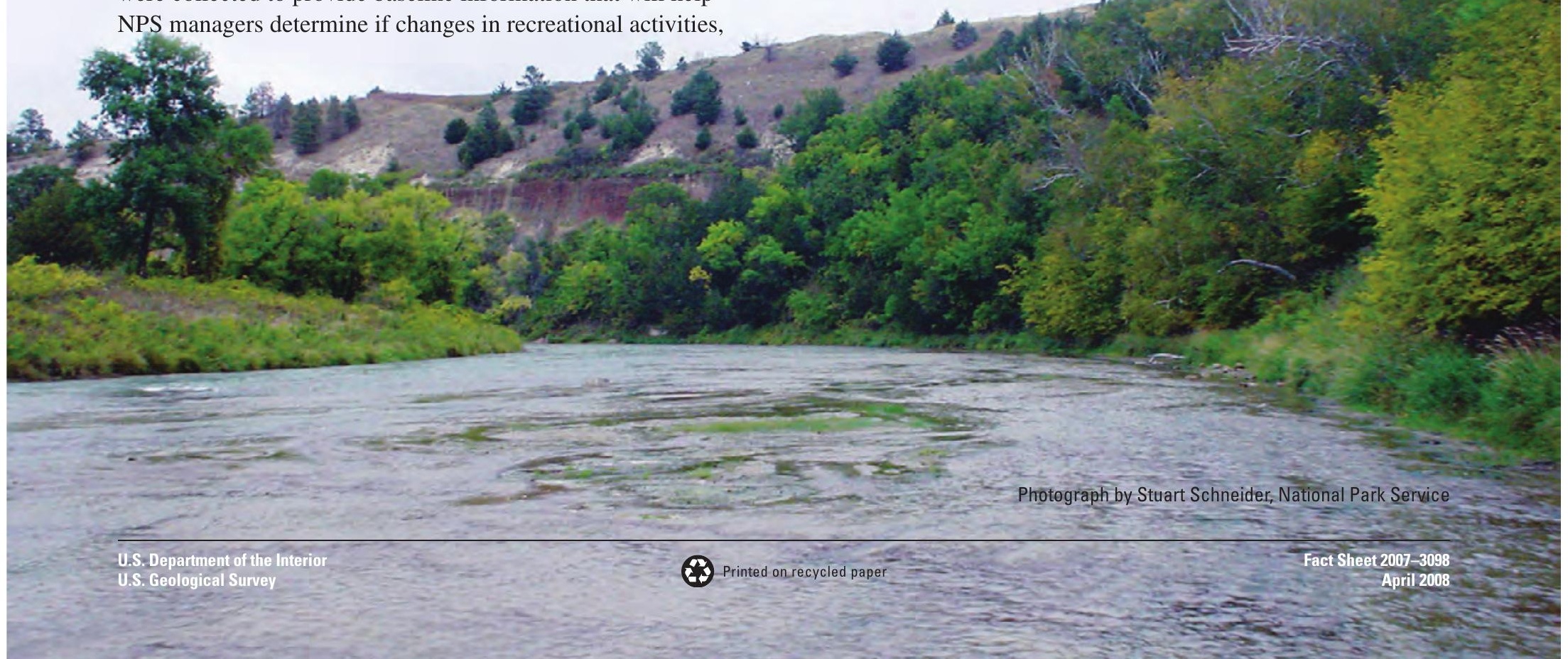




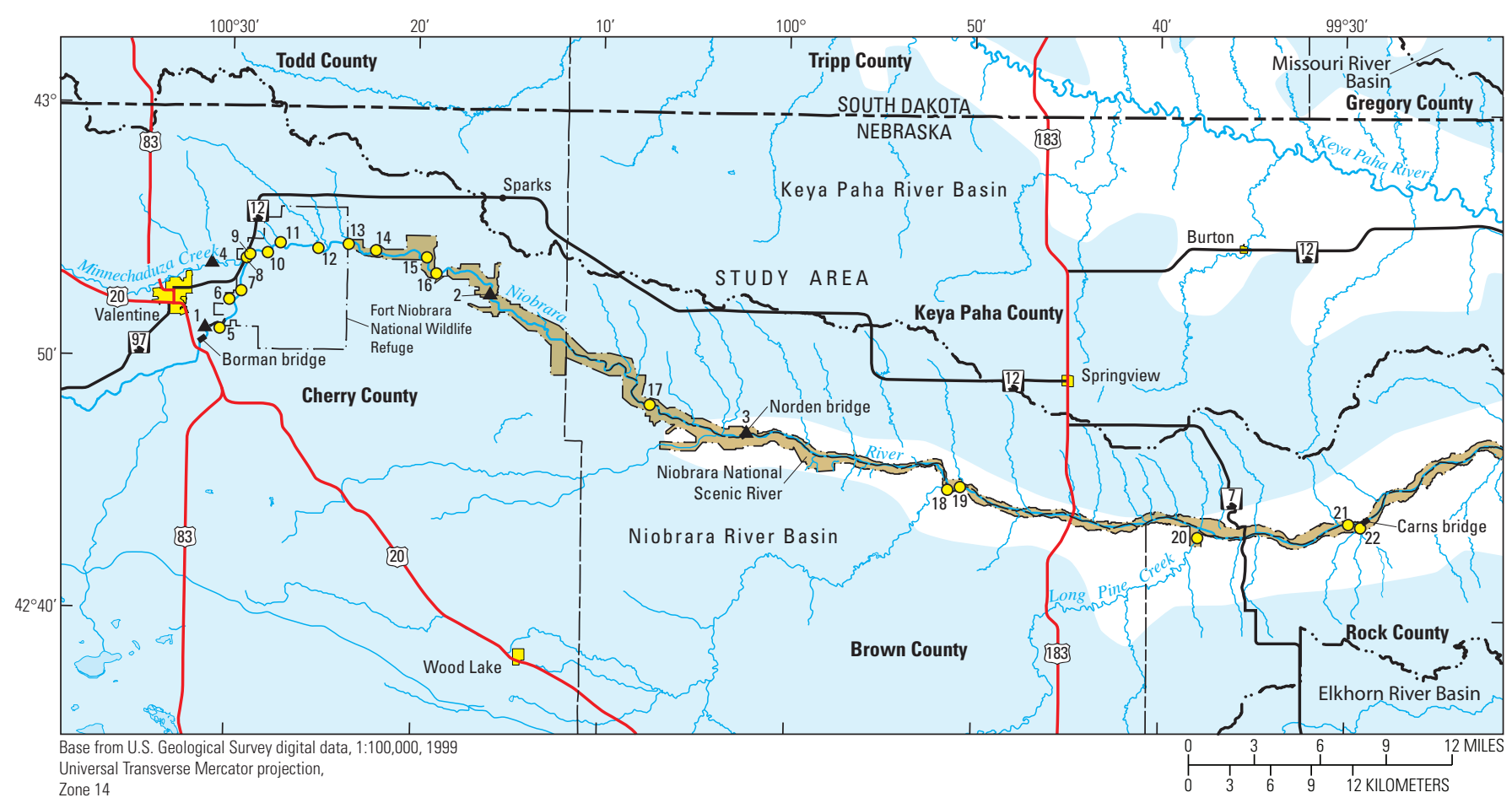

Horizontal coordinate information is referenced to the North American Datum of 1983 (NAD 83)

\section{EXPLANATION}

Extent of High Plains aquifer

Niobrara National Scenic River designation

\section{-..- Boundary of drainage basin \\ ${ }^{3} \quad$ Water-quality sampling site and map number \\ ${ }^{17} \mathrm{O} \quad$ Fish community sampling site and map number}

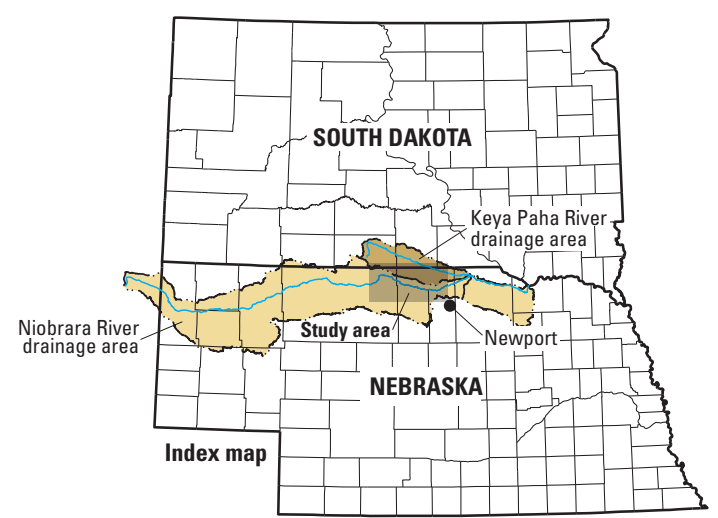

Figure 1. Location of the study area for water-quality and fish-community data collection for the Niobrara National Scenic River, Nebraska, 2003-05.

June to September 2003 and from May to December 2004. Filtered (0.45-micron) and unfiltered samples were collected to evaluate dissolved and total concentrations. Samples were collected twice in June 2003 and once per month from July through September 2003 using methods described in Meyers (2004) and Wilde (variously dated), and U.S. Geological Survey (variously dated). Samples were collected monthly from May 2004 through December 2004. Three of the four sampling sites were located along the Niobrara River-upstream from Fort Niobrara National Wildlife Refuge at the Borman Bridge (site 1, USGS station 06460800), at Berry Bridge near Sparks (site 2, USGS station 06461500), and at the Norden Bridge (site 3, USGS station 06462000). The fourth site was located on Minnechaduza Creek downstream from Valentine (site 4, USGS station 06461010). A continuous streamflow recorder has been in operation at Berry Bridge near Sparks (site 2) since 1946.

Fish-community sampling occurred once at each of 18 sites of which 7 were located on the Niobrara River main stem and 11 were located on selected tributaries (fig. 1). Potential fish migration barriers occurred within the reach such as the Cornell Dam, a large knickpoint near the Norden bridge, and rock riffles. Samples were obtained using electroshocking and seining techniques (fig. 2) primarily during early to mid-September 2003-05.

\section{Water-Quality Properties}

During water-quality sample collection, study personnel measured specific conductance, $\mathrm{pH}$, air and water temperatures, and dissolved oxygen concentration using calibrated instruments (Wilde, chapter sections variously dated). Specific conductance values measured at the Niobrara River sites ranged from 198 to 229 microsiemens per centimeter at 25 degrees Celsius $(\mu \mathrm{S} / \mathrm{cm})$ and were less than values measured in Minnechaduza Creek (site 4), which ranged from 285 to $335 \mu \mathrm{S} / \mathrm{cm}$. Specific conductance observations at individual sites did not 


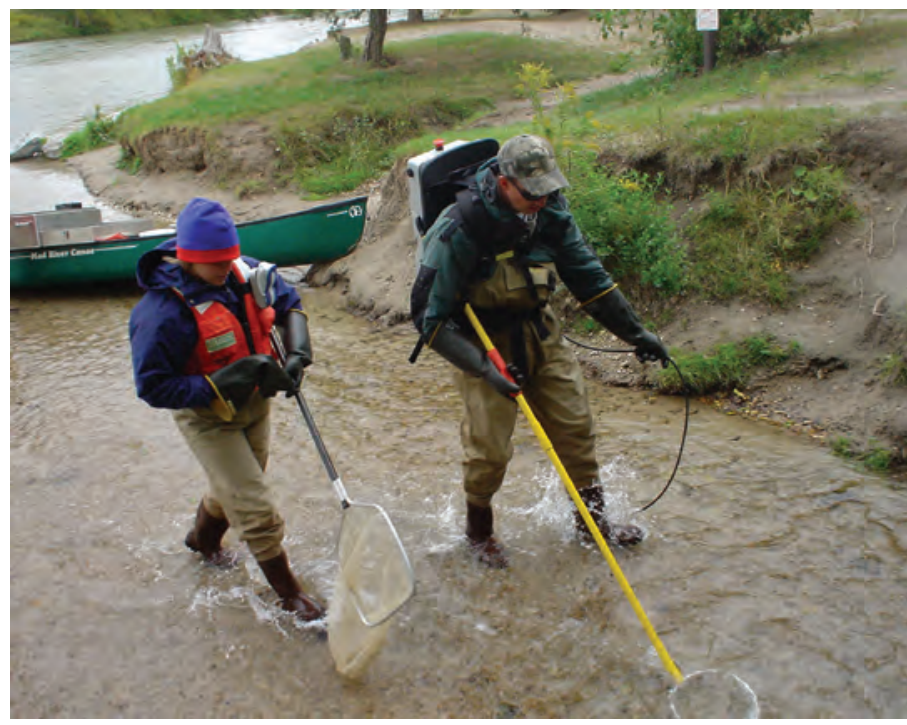

Figure 2. Collecting fish by electroshocking technique, Niobrara River Nebraska. Photograph by Stuart Schneider, National Park Service.

vary substantially. At the Niobrara River sites, $\mathrm{pH}$ values varied from 7.8 to 8.7 standard units, and in general, the values were smallest at the most upstream site (Borman Bridge, site 1). In most cases, $\mathrm{pH}$ values were highest at the Minnechaduza Creek site (site 4), where $\mathrm{pH}$ ranged from 8.1 to 8.8 and the highest $\mathrm{pH}$ value (8.8) of all samples at all sites was measured in May 2004. The highest water temperatures usually were measured when the highest air temperatures were measured, and the lowest water temperatures were measured when the lowest air temperatures were measured at all four water-quality sites. Dissolved oxygen concentrations were larger than 7.2 milligrams per liter $(\mathrm{mg} / \mathrm{L})$ in all samples and typically were larger when water temperatures were low. Dissolved oxygen concentrations usually were largest at Berry Bridge near Sparks (site 2) and smallest at Norden Bridge (site 3).

\section{Major lons}

All water-quality samples were analyzed for 10 major ions at the USGS National Water Quality Laboratory (NWQL) in Lakewood, Colorado, using methods described in Fishman (1993). The dominant cation in water at the sampling sites was calcium. Sulfate and chloride were the dominant anions. Samples from the Niobrara River sites showed stable major ion concentrations throughout the sampling period and were less than concentrations in Minnechaduza Creek. Potassium concentrations ranged from 5 to $7 \mathrm{mg} / \mathrm{L}$ in samples from Niobrara River sites and from 6 to $10 \mathrm{mg} / \mathrm{L}$ in samples from the Minnechaduza site. Silica concentrations ranged from 40 to $70 \mathrm{mg} / \mathrm{L}$ in samples from the Niobrara River and from 42 to $47 \mathrm{mg} / \mathrm{L}$ in samples from Minnechaduza Creek. Iron concentrations were near or less than the minimum reporting level (8 micrograms per liter $(\mu \mathrm{g} / \mathrm{L}))$ in all samples. Fluoride concentrations ranged from 0.3 to $0.5 \mathrm{mg} / \mathrm{L}$ in all samples.

\section{Nutrients}

Nutrients, such as nitrogen and phosphorus compounds, occur naturally in surface water, but elevated concentrations often are associated with agricultural runoff and with detergents and chemicals found in municipal wastewater discharges and septic systems (Mueller and Helsel, 1996). Excessive nutrient concentrations can trigger algal blooms (U.S. Environmental Protection Agency, 1986) that may cause decreases in dissolved oxygen and increases in suspended materials. All samples were analyzed for eight nutrient compounds at the NWQL (Fishman, 1993). Nitrite plus nitrate was less than $1 \mathrm{mg} / \mathrm{L}$ as nitrogen in all of the samples. In most months, water from the Minnechaduza Creek site showed the largest concentrations of unfiltered ammonia plus organic nitrogen, filtered ammonia plus organic nitrogen, nitrite, nitrate, filtered phosphorus, and organophosphates. Of the 51 unfiltered samples collected in the Niobrara NSR that were analyzed for total phosphorus, 45 exceeded the U.S. Environmental Protection Agency (USEPA) recommendation of $0.1 \mathrm{mg} / \mathrm{L}$ for avoiding algal blooms (U.S. Environmental Protection Agency, 1986). In general, phosphorus concentrations in samples from the Minnechaduza Creek site were higher than the phosphorus concentrations at other sites for the corresponding sampling event.

\section{Trace Elements}

Naturally occurring arsenic can be found in deposits of the Cretaceous-aged Niobrara Formation and Carlile Shale of the Colorado Group that underlie the study area (Bradley, 1956). Uranium is known to occur in water-bearing units of the Brule Formation and Chadron Formation in Nebraska west of the study area (Dickinson, 1991). These compounds can be carried to streams from ground water and on sediment during surface runoff events. For the protection of aquatic life, the Nebraska Department of Environmental Quality criteria (Nebraska Department of Environmental Quality, 2006) require longterm average arsenic concentrations to be less than $16.7 \mu \mathrm{g} / \mathrm{L}$. Although there is no State standard for dissolved uranium for the protection of aquatic life, uranium concentrations in publicdrinking water must be less than $30 \mu \mathrm{g} / \mathrm{L}$ (Nebraska Department of Environmental Quality, 2006). All samples were analyzed for trace elements arsenic, lead and uranium at the NWQL (Faires, 1993). Concentrations for trace elements including arsenic, lead, and uranium were determined in samples from Minnechaduza Creek (site 4) and on the Niobrara River at the Borman Bridge (site 1). Arsenic concentrations were similar at the two sites and ranged from 4.9 to $7.2 \mu \mathrm{g} / \mathrm{L}$. Lead concentrations were near or less than the minimum reporting level of the laboratory method $(0.08 \mu \mathrm{g} / \mathrm{L})$. Uranium concentrations ranged from 0.81 to 1.62 $\mu \mathrm{g} / \mathrm{L}$, with slightly higher concentrations detected in samples from the Minnechaduza Creek site.

\section{Pesticides}

Pesticides are commonly detected at surface-water sites in Nebraska because of widespread use in agriculture and urban settings (Larson and others, 1999). Water samples collected near the Norden Bridge (site 3) were analyzed for 65 pesticide compounds at the NWQL (Zaugg and others, 1995). Four compounds were detected in trace concentrations [atrazine, 2-chloro-4-isopropylamino-6-amino-s-triazine (an atrazine degradate), metolachlor, and trifluralin]. Atrazine, metolachlor, and trifluran are herbicides used to control weeds in corn, soybeans, and other crops. One compound, Deet, was detected at concen- 
trations greater than $1 \mu \mathrm{g} / \mathrm{L}$. Deet, which is commonly found in insect repellents, was detected in the August 2004 samples from Minnechaduza Creek (site 4), and from the Niobrara River (sites 2 and 3) and in three September 2004 samples (sites 1, 2, and 4). No other pesticides were detected.

\section{Organic Wastewater Compounds}

Organic wastewater compounds (OWCs) are chemicals such as household, industrial, and agricultural-use compounds, pharmaceuticals, antibiotics, and sterols and hormones that can enter streams and ground water through discharge from municipal and industrial wastewater-treatment plants, domestic septic systems, animal feedlots, and other sources (Lee and others, 2004). Samples at all 4 sites were analyzed for the presence of 62 OWCs at the NWQL using methods developed by the USGS (Zaugg and others, 2002). Tris(2-butoxyethyl) phosphate, a flame retardant, was detected at a low concentration in one sample from Minnechaduza Creek (site 4) on August 23, 2003. This detection and the detection of Deet coincide with the peak period of recreational activity and with locations downstream from municipal and recreational uses and sites where fire-fighting activities may have occurred. Five other organic wastewater compounds (isophorone, napthalene, phenanthrene, 1,4-dichlorobenzene, and caffeine) were present at detectable concentrations, but the concentrations of these compounds were too small to be quantified.

\section{Bacteria}

Surface water commonly contains Escherichia coli (E. coli) bacteria originating from humans, livestock, and wildlife (Hyer and Moyer, 2003). Exposure to elevated densities of $E$. coli can pose health risks to humans recreating in or around the affected water body. Nebraska water-quality standards require that the geometric mean of E. coli densities (based on a minimum of 5 samples collected within a 30-day period) in streams designated as moderately used recreational water must not exceed 298 colonies per 100 milliliter $(\mathrm{col} / 100 \mathrm{~mL})$ (Nebraska Department of Environmental Quality, 2006). Grab samples for $E$. coli were collected at all four sites using methods described in Meyers (2004) and processed in sterilized equipment for each sample collection, except the first sample collection in June 2003 did not include bacteria samples. Samples were cultured using the modified mTEC method (U.S. Environmental Protection Agency, 2002). E. coli were detected in all samples, and the density of $298 \mathrm{col} / 100 \mathrm{~mL}$ was exceeded during two sample collections. The largest E. coli observed density during the study was $1,000 \mathrm{col} /$ $100 \mathrm{~mL}$ was detected at the Minnechaduza Creek (site 4) in early November 2004. The largest density measured on the Niobrara River was $450 \mathrm{col} / 100 \mathrm{~mL}$ at site 1 in a late June 2003 sample following several days of intense rain. Because these were individual sample collections rather than sets of five per month, they do not necessarily indicate that $E$. coli criteria exceeded the water-quality standards for Nebraska.

\section{Suspended Sediment}

Large suspended-sediment concentrations can have negative effects on the habitat, health, and behavior of aquatic life (Waters, 1995). Suspended-sediment samples were collected concurrently with each water-quality sample. In general, suspended-sediment concentrations increased downstream on the Niobrara River and ranged from 22 to $1,170 \mathrm{mg} / \mathrm{L}$ for sites on the Niobrara River. Suspended-sediment concentrations in Minnechaduza Creek were less than $30 \mathrm{mg} / \mathrm{L}$ for all samples. Samples collected in late June 2003 did not have substantially higher sediment concentrations than samples collected in other months.

\section{Fish-Community Data}

At 18 sites on the Niobrara River and its tributaries (table 1), fish were collected using electroshocking and seining techniques (Meador and others, 1993). Twenty-seven different species were identified within the study area, and the greatest number of unique species was found at a site on the Niobrara River upstream from Smith Falls (17 unique species collected). However, the overall number of unique species was greater at sites downstream from the Norden Bridge. The Norden Bridge location marks a distinct change from a swift, narrow channel upstream to a broad, shallow channel downstream with fewer riffles and pebble beds than upstream from the bridge. Additionally, the Norden Bridge is located near a steep drop in streambed elevation, which may be an obstacle to upstream migration. Some species, such as red shiner (Notropis lutrensis), sand shiner (Notropis stramineus), and bigmouth shiner (Notropis dorsalis) were numerous and widespread and, in general, appeared to lack abnormalities. Longnose dace (Rhinichthys cataractae) were present at most sites but were recorded in fewer numbers at sites downstream from the Norden Bridge. The presence of river carpsuckers (Carpiodes carpio) and quillback carpsuckers (Carpiodes cyprinus) was confined to reaches downstream from the Norden Bridge. Other species, such as brown trout (Salmo trutta), rainbow trout (Oncorhynchus mykiss), brook stickleback (Culaea inconstans), plains topminnow (Fundulus sciadicus), and western silvery minnow (Hybothnathus argyritis), were limited to just a few sites. Gamefish such as largemouth bass (Micropterus salmoides), green sunfish (Lepomis cyanellus), bluegill (Lepomis macrochirus), and channel catfish (Ictalurus punctatus) were found

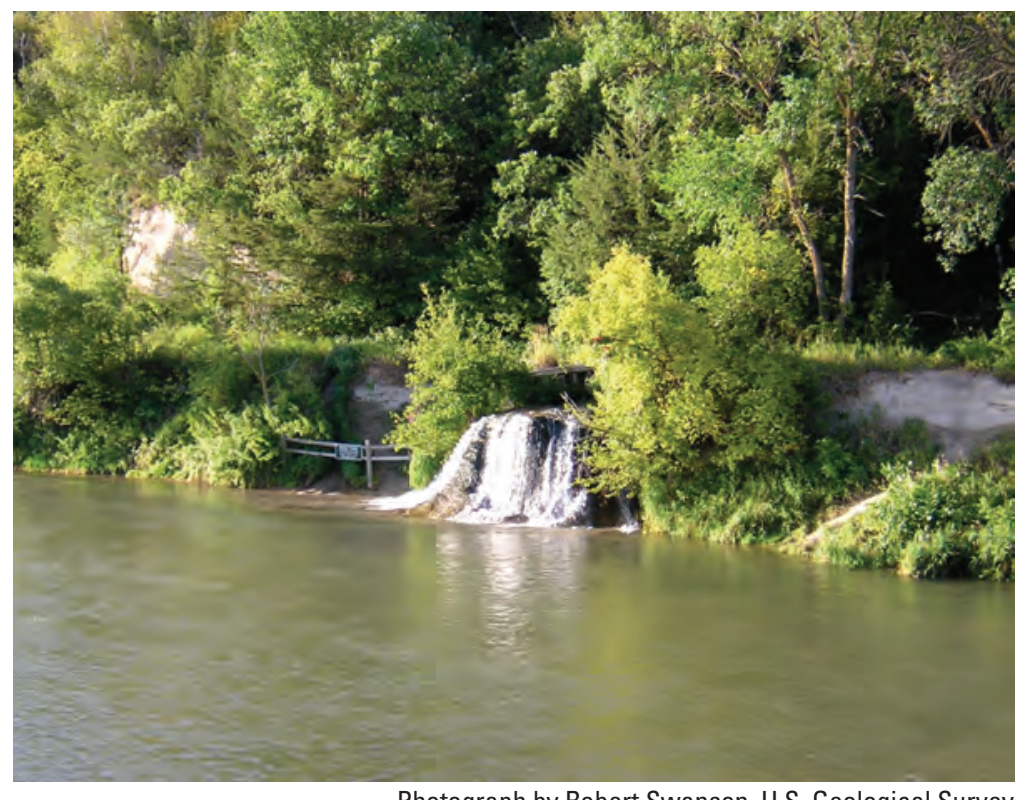


Table 1. Fish species collected using electroshocking and seining techniques at selected sites on the Niobrara River.

[BLG, bluegill; BMS, bigmouth shiner; BM, brassy minnow; BKS, brook stickleback; BKT, brown trout ; CCF, channel catfish; CCA, common carp; CCH, creek chub; FHC, flathead chub; FHM, fathead minnow; GP, grass pickerel; GSF, green sunfish; LMB, largemouth bass; LND, longnose dace; MC, mirror carp; NP, northern pike; PTM, plains top minnow; QCS, quillback carpsucker: RBT, rainbow trout; RCS, river carpsucker; RSH, red shiner; SSH, sand shiner; SRH, shorthead redhorse; STC, stone cat; WSV, western silvery minnow; WSK, white sucker; YWP, yellow perch]

\begin{tabular}{|c|c|c|c|c|c|}
\hline Site & Latitude & Longitude & Site & Date & Species Identified \\
\hline 5 & 42.851 & -100.508 & $\begin{array}{l}\text { Niobrara } \mathrm{R} \text { below Borman Bridge near } \\
\text { Valentine, Nebr. }\end{array}$ & $9 / 15 / 2003$ & $\begin{array}{l}\text { BMS, BKT, CCF, CCA, GP, LND, NP, RSH, SSH, } \\
\text { SRH, STC, WSK }\end{array}$ \\
\hline 7 & 42.877 & -100.490 & Niobrara Mainstem above Cornell Dam & $9 / 16 / 2003$ & $\begin{array}{l}\text { BMS, BKT, FHM, GP, LND, NP, RSH, SSH, SRH, } \\
\text { WSK }\end{array}$ \\
\hline 8 & 42.898 & -100.485 & Minnechaduza Creek & $9 / 16 / 2003$ & CCH, LMB, LND, SRH, STC, WSK \\
\hline 10 & 42.902 & -100.466 & $\begin{array}{l}\text { Niobrara Mainstem just upstream from } \\
\text { Fort Falls }\end{array}$ & $9 / 17 / 2003$ & $\begin{array}{l}\text { BMS, CCA, CCH, GSF, LND, RSH, SSH, SRH, } \\
\text { STC, WSK }\end{array}$ \\
\hline 11 & 42.905 & -100.421 & Big Beaver Creek & $9 / 17 / 2003$ & BM, CCH, FHM, LND \\
\hline 12 & 42.908 & -100.394 & Crooked Creek & $9 / 17 / 2003$ & $\mathrm{CCH}, \mathrm{LND}$ \\
\hline 16 & 42.908 & -100.455 & Unnamed Trib 3 & $9 / 17 / 2003$ & None \\
\hline 17 & 42.721 & -99.631 & Long Pine Creek & 9/9/2004 & $\begin{array}{l}\text { BMS, BM, BKT, CCH, FHM, LMB, LND, RSH, } \\
\text { SSH, SRH, STC, WSK, FHC, BLG, RCS }\end{array}$ \\
\hline 18 & 42.728 & -99.486 & Laughing Water Creek & $9 / 10 / 2004$ & BKT, LND, RSH \\
\hline 19 & 42.753 & -99.844 & $\begin{array}{l}\text { Niobrara Mainstem below Meadville } \\
\text { Bridge }\end{array}$ & $9 / 8 / 2004$ & $\begin{array}{l}\text { BMS, BM, CCF, CCH, FHM, LMB, LND, PTM, } \\
\text { RSH, SSH, SRH, STC, WSK, FHC, BLG, RCS, } \\
\text { QCS }\end{array}$ \\
\hline 20 & 42.751 & -99.855 & Plum Creek & 9/7/2004 & $\begin{array}{l}\text { BMS, BM, CCH, FHM, GSF, LMB, LND, PTM, } \\
\text { RSH, SSH, SRH, WSK, BLG, RCS }\end{array}$ \\
\hline 21 & 42.730 & -99.497 & $\begin{array}{l}\text { Niobrara River Upstream from Carns } \\
\text { Bridge }\end{array}$ & $9 / 13 / 2005$ & $\begin{array}{l}\text { BMS, BM, CCF, CCA, CCH, FHM, LMB, RSH, } \\
\text { SSH, SRH, STC, WSK, FHC, RCS, QCS }\end{array}$ \\
\hline
\end{tabular}

throughout the Niobrara NSR, but more commonly downstream from the Norden Bridge. Grass pickerel (Esox americanus vermiculatus) and northern pike (Esox lucius) were collected in reaches upstream from Cornell Dam.

\section{Acknowledgements}

The author thanks the staff of the National Park Service for their cooperation and contribution to this study. Appreciation is extended to the landowners for providing access to sampling sites.

\section{-By B.J. Dietsch}

\section{References Cited}

Bradley, Edward, 1956, Geology and ground-water resources of the upper Niobrara River basin, Nebraska and Wyoming, with a section on Chemical quality of the ground water, by F.H. Rainwater: U.S. Geological Survey Water-Supply Paper 1368, 70 p.
Dickinson, K.A., 1991, Uranium diagenesis in evaporate lacustrine mudstone of the Oligocene White River Group, Dawes County, Nebraska: U.S. Geological Survey Professional Paper 17, 69 p.

Faires, L.M., 1993, Methods of analysis by the U.S. Geological Survey National Water Quality Laboratory-Determination of metals in water by inductively coupled plasma-mass spectrometry: U.S. Geological Survey Open-File Report 92-634, $28 \mathrm{p}$.

Fishman, M.J., ed., 1993, Methods of analysis by the U.S. Geological Survey National Water Quality LaboratoryDetermination of inorganic and organic constituents in water and fluvial sediments: U.S. Geological Survey Open-File Report 93-125, 217 p.

Hitch, D.E., Hull, S.H., Walczyk, V.C., Miller, J.D., and Drudik, R.A., 2004, Water resources data, Nebraska, water year 2003: U.S. Geological Survey Water-Data Report NE-03-1, 470 p. 
Hitch, D.E., Hull, S.H., Walczyk, V.C., Miller, J.D., and Drudik, R.A., 2005, Water resources data, Nebraska, water year 2004: U.S. Geological Survey Water-Data Report NE-04-1, 671 p.

Hyer, K.E., and Moyer, D.L., 2003, Patterns and sources of fecal coliform bacteria in three streams in Virginia, 1999-2000: U.S. Geological Survey Water-Resources Investigations Report 03-4115, 76 p.

Lee, K.E., Barber, L.B., Furlong, E.T., Cahill, J.D., Kolpin, D.W., Meyer, M.T., and Zaugg, S.D., 2004. Presence and distribution of organic wastewater compounds in wastewater, surface, ground, and drinking waters, Minnesota, 2000-2002: U.S. Geological Survey Scientific Investigation Report 2004-5138, 47 p.

Meador, M.R., Cuffney, T.F., and Gurtz, M.E., 1993, Methods for sampling fish communities as part of the National WaterQuality Assessment Program: U.S. Geological Survey OpenFile Report 93-104, 40 p.

Meyers, D.N., 2004, Fecal indicator bacteria (3d ed.): U.S. Geological Survey Techniques of Water-Resources Investigations, book 9, chap. A7, section 7.1, accessed April 30, 2007 , at http://pubs.water.usgs.gov/twri9A7/.

Mueller, D.K., and Helsel, D.R., 1996, Nutrients in the Nation's water-Too much of a good thing?: U.S. Geological Survey Circular 1136, 24 p.

Larson, S.J., Gilliom, R.J., and Capel, P.D., 1999, Pesticides in Streams of the United States-Initial Results from the National Water-Quality Assessment Program U.S. Geological Survey Water-Resources Investigations Report 98-4222, $92 \mathrm{p}$.

National Park Service, 2005, Total recreational visits for 2004: National Park Service information available on Web, accessed September 12, 2005, at http://www.nps.gov/niob/ pphtml/facts.html.

Nebraska Department of Environmental Quality, 2006, Title 117-Nebraska surface water quality standards, Lincoln, Nebraska Department of Environmental Quality, accessed
April 30, 2007, at http://www.deq.state.ne.us/RuleAndR.nsf/ pages/117-TOC.

U.S. Environmental Protection Agency, 1986, Quality criteria for water, 1986: U.S. Environmental Protection Agency Report 440/5-86-001, unnumbered pages.

U.S. Environmental Protection Agency, 2002, Method 1603 - Escherichia coli in water by membrane filtration using modified membrane-thermotolerant Escherichia coli agar: Washington, D.C., EPA Report 821-R-02-23, 9 p.

U.S. Geological Survey, variously dated, National field manual for the collection of water-quality data: U.S. Geological Survey Techniques of Water-Resources Investigations, book 9, chaps. A1-A9, available online at http://pubs.water.usgs. gov/twri9A.

Waters, T.F., 1995, Sediment in streams-sources, biological effects, and control: Bethesda, Md., American Fisheries Society Monograph 7, $251 \mathrm{p}$.

Wilde, F.D., ed., chapter sections variously dated, Field measurements: U.S. Geological Survey Techniques of WaterResources Investigations, book 9, chap. A6, accessed April 30, 2007, at http://pubs.water.usgs.gov/twri9A6/.

Zaugg, S.D., Sandstrom, M.W., Smith, S.G., and Fehlberg, K.M., 1995, Methods of analysis by the U.S. Geological Survey National Water Quality Laboratory-Determination of pesticides in water by C-18 solid-phase extraction and capillary-column gas chromatography/mass spectrometry with selected-ion monitoring: U.S. Geological Survey OpenFile Report 95-181, 60 p.

Zaugg, S.D., Smith, S.G., Schroeder, M.P., Barber, L.B., and Burkhardt, M.R., 2002, Methods of analysis by the U.S. Geological Survey National Water-Quality Laboratorydetermination of wastewater compounds by polystyrene-divinylbenzene solid-phase extraction and capillary-column gas chromatography/mass spectrometry: U.S. Geological Survey Water-Resources Investigations Report 01-4186, 37 p.

Photograph by Robert Swanson, U.S. Geological Survey

\author{
For further information contact: \\ Robert Swanson, Director \\ U.S. Geological Survey \\ Nebraska Water Science Center \\ Lincoln, NE 68512 \\ (402) 328-4100
}

